\title{
IFRS ADOPTING PROCESS IN ROMANIAN BANKS - IMPACT ON INDEPENDENT AUDIT OF FINANCIAL STATEMENTS
}

\author{
Adela Socol ${ }^{l}$
}

\begin{abstract}
The purpose of this paper is to study the manner in which the banking independent auditors' mission could be influenced by the International Financial Reporting Standards IFRS adoption in Romanian banks beginning with the financial year ending 31 December 2012. The paper aims to develop a theoretical and empirical comparative analysis of IFRS and Romanian Accounting Standards applied in the banking field by examining a bank's Financial Statements (Balance Sheet) for the financial exercise ending 31 December 2011. Our analysis illustrates the differences between these two categories of standards and configures the causes of the differences and the way in which the new IFRS may affect the independent audit process of the financial statements of banks. Our approach represents a forward-looking landing of the challenges of the audit of the IFRS banking financial statements, because the financial statements of the year ending to 31 December 2012 will be the first issued according to the new accounting rules based on IFRS. We study the Auditors' Reports for the year 2011 of the listed Romanian banks at the Bucharest Exchange Stock and emphasize the auditors' fear regarding to the subsequent events, after the beginning of 2012, referring to the new IFRS standards applicable from 1 January 2012.
\end{abstract}

Key words: IFRS applying, active banks from Romania, independent audit, financial statements of banks

JEL codes: M42, G21, G28

\section{Introduction}

Economic theory suggests the public role of the banks in their quality of credit institutions, since banks support the economic growth, facilitate the informational process between investors and lenders and are responsible for the investors' funds. The banks' transparency and disclosures appear in this context like main desideratum promoted by the national authorities of banking supervision, that have to harmonize the market discipline disclosures with the accounting disclosures. The market discipline presumes the application of the international provisions in the field, contained now by the Basel III - the global regulatory framework for more resilient banks and banking systems, revised June 2011. It intends to especially improve the transparency of regulatory capital of the banks, as the Basel II Agreement, the Third Pillar introduced from 2005 the market discipline, through developing a set of disclosure requirements which impose that banks assess information regarding to scope of application, capital, risk exposures, risk assessment processes and capital adequacy.

The second banking disclosures item refers to accounting requirements that impose those banks abide by the national regulation regarding to financial statements publication. Harmonization in accounting represented a long time wished purpose in the accounting field, since '60 years. History of accounting standardization implied during the years the different institutions and methods to establish the proper standards. Fussy aspects derived from the legitimization of the standards' issuers, the adopting processes, including the consultative documents and publication and the obligatory character of the standards. After some decades of accounting standardization, the last years brought a common language in accounting through the International Financial Reporting

\footnotetext{
1 “1 Decembrie 1918” University of Alba Iulia, Romania,e-mail: adelasocol@yahoo.com
} 
Standards, which generates the accounting convergence among the users of these standards. The responsible body for the development and publication of IAS/ new IFRSs is IASB International Accounting Standards Board, an independent standard-setting body of the IFRS Foundation that established the mission to develop, in the public interest, a single set of high quality, understandable, enforceable and globally accepted International Financial Reporting Standards IFRSs. The initial and hinted declared beneficiaries of these standards were the quoted companies in the capital markets, in order to promote the unitary accounting behavior between these companies. Chronological, the next companies aimed by the IAS/IFRS implementation were the public interest companies, among which we distinguish the credit institutions.

We develop this research about the banks in their quality of credit institutions, for the purpose of present the actual status of banking Romanian accounting according to IFRS and its implications on the independent banking audit process. The paper is organized as follow: the first section is theoretical, in order to present the actual stage of knowledge in the area. Also, it summarizes the recent evolution of banking accounting regulation in Romania and the IFRS framework. The next section develops the comparative analysis between IFRS and banking Romanian Accounting Standards and the implication of banking IFRS adoption on the independent audit. Some overall remarks conclude the paper.

\section{Research Methodology and Hypotheses Development}

We based the theoretical part of the research on the interpreting techniques and literature analysis, which belong to interpretive and critical paradigm. The used research methods presumed the studying of the literature and the legislative banking norms according to the established research objectives.

Also, we used the quantitative and qualitative techniques and the constructivist approach, in order to build the study case. The problem is presented from the general and technical features of IFRS towards the specific situation of the banking accounting in Romania. We suppose that accounting banking rules according to IFRS can have an impact on the financial auditors' mission. Our research hypothesis is that the IFRS applying in Romanian banks will have an impact on the audit process.

We collect the data published in the official reports of the banking societies active from Romania. We focus on the Audit Reports of the main banking institutions that activate in Romania, for the financial exercise ending 31 December 2011. We choose the listed banks at the Bucharest Stock Exchange and intend to find how the accounting regulatory framework according to IFRS could influence the work of the banking auditors. Also, in order to underline the challenges of the IFRS adoption in the Romanian banking system, we develop a case study based on the original individual Financial Statements of Banca Comerciala Carpatica SA for the financial exercise as at 31 December 2011, elaborated in accordance with Order No. 15/2009 of the Chairman of the National Bank of Romania Board with subsequent amendments and additions, regarding to preparing the financial statements according to IFRS.

\section{Theoretical background}

One of the general assumptions is that companies are significantly affected by IAS/IFRS adoption. Overwhelming majority of the studies underline the advantages of the IFRS adopting for the companies, but there are also other authors which formulate objections and critiques, referring to the actual milieu of IAS/IFRS that may not cover the interests of wider stakeholders, such as the public and the other users (Brown, 2004; Biondi and Suzuki, 2007). They consider that the activity of IAS/IFRS may offer a cosy arrangement for a narrow band of stakeholders' such a investment bankers, international institutional investors and Big Four accounting firms, but not for the other member groups of the global community that IAS/IFRS claim to serve. Another authors estimate 
that the benefits of IFRS adoption must be substantially smaller than what academics generally have estimated them to be (Christensen, 2012).

On the other hand, we found proves of advantages of IFRS adopting by companies. For example, there are opinions that the features of quality of financial statements - reliability and comparability - are improved by the adoption and application of IFRS in developing countries (Ballas et. al, 2010).

The specialized studies that explore the banking field rather underline the advantages of IFRS banking application, like Agostino's, that investigates whether the value relevance increased after the adoption of IAS/IFRS by listed banks in Europe. Using a standard value-relevance model, they examine the value relevance of earnings and book value for 221 listed banks from 2000 to 2006. Their results provide evidence that IFRS may have beneficial effects on the financial markets' transparency, even though they may also increase the stock prices' volatility (Agostino et al., 2010). Empirical evidence on the accounting quality implications of the mandatory applications of IFRS within the banking industry predicts and finds that the application of the stricter impairment rules reduces discretion in the main operating accrual in banks' accounts, the loan loss provision. The authors analyzed the implications of mandatory IFRS adoption on the accounting quality of banks in 12 EU countries. They provide evidence that the restriction to incurred losses under IFRS significantly reduces the ability of banks to engage in income smoothing and consider that this effect is less pronounced in countries with widely dispersed ownership structures and strict bank supervision (Gebhardt and Novotny-Farcas, 2010).

Prior researches underline the influence of banking accounting on value relevance. Differences in accounting measurement practices were attest like one of the most influencing factors affecting the extent of value relevance of earnings and book values of banks (Anandarajan et. al, 2011). The authors used more than 28000 observations of 813 banking institutions in 38 countries during 1993-2004.

Some authors (Bansal et. al, 2011) studied the major areas affected by the IFRS applying in the banking sector, for India's case: loan and investment impairment, fair value, derivatives and hedge accounting, de-recognition of financial assets and consolidation. They concluded the difficulty of the process of IFRS adopting and the challenges for the banks, which need the regulatory sponsorship, the investments in the banking systems and processes, and sound market practices in that banking domains where the judgment is crucial. Also the Indian banking system was studied from the impact of IFRS on the Indian banking industry perspective by Firoz et. al (Firoz et. al, 2012). The authors realized a critical analysis of financial statement of the Indian banking industry, such a business per employee, capital and reserve, investments and advances, net NPA Ratios and the impact thereon of relevant provisions of IFRS. They conclude that the implementation of IFRS shall have the major impact over the advances, financial instruments, investments and but not limited to heavy investment on updating of information technology system.

An interesting topic of the last few years is to study the IFRS implementation in the banking field for different studied European countries. The bellow map present the European situation regarding to the IFRS application in the banking systems in 2011. Generally, we remark that IFRS in banking systems are not widespread in Central and Eastern Europe in their quality of compulsory standards, with some exceptions Austria, Italy, Bulgaria, Greece.

Few countries permit that the banks can opt to voluntary adopting of IFRS, e.g. Great Britain, Czech Republic. In Czech Republic, a large majority of banks (84\% of the banking sector's total balance sheet) apply the IFRS, although they also report according to local standard, but the differences between the IFRS and the local standard are insignificant for banks (International Monetary Fund, 2012). 


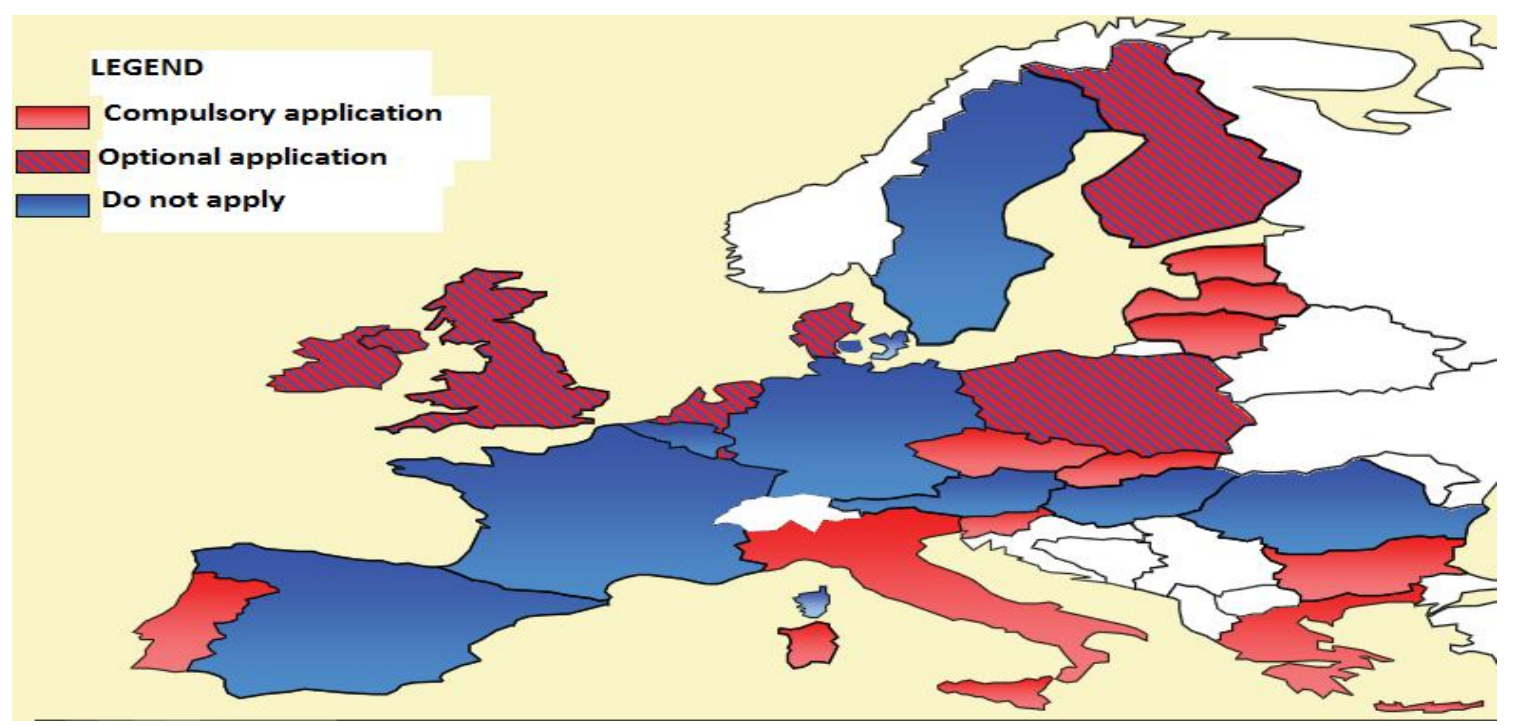

\section{Figure no. 1.- IFRS Application in credit institution for individual Financial Statements - Europe 2011}

Source: National Bank of Romania, Stefan C., NBR Settlements in the IFRS Implementation Context

In 2011 Romania did not apply IFRS rules in the banking field. Just from 1999 in Romania the accounting harmonization program of the Romanian authorities intended to gradually implementing of the International Accounting Standards. The first category of entities that applied IAS in 2000 was the listed companies at the Bucharest Exchange Stock and the national companies. Annually, during 2000-2006, the Romanian authorities established the minimum quantitative criteria regarding to the turnover, total assets and number of employers, in order to select the companies that have to apply IAS.

We remark a limited adoption of IAS, based on great values of mentioned criteria and on legislative incoherence. For example, in 2004, Romania was studied from the IFRS adoption perspective among another 16 European States in its quality at that time of EU candidate country (Larson and Street, 2004). The authors mentioned several obstacles to accounting convergence: insufficient guidance on first-time application of IFRS and the tax-driven nature of national accounting requirements.

Only beginning with 2005, the credit institutions prepared their consolidated financial statements according to IAS, while the individual statements were elaborated according to European Directives. In this context, the credit institutions prepared since 2012 two sets of financial statements - one for the State's informing and one for own needs of information. Since 2012 the individual component of the banking groups used local General Accepted Accounting Principles Romanian Accounting Standards, according to European Directives.

Later, the financial statements of the banking active component and groups from Romania are elaborated in accordance with International Financial Reporting Standards. Starting with 2010 the National Bank of Romania issued certain national provisions regarding to adoption of the International Financial Reporting Standards by Romanian banks beginning with the financial year ending 31 December 2012 (Order 15/2009, Order no. 9/2010, Order no. 27/2010, Order no. 26/2010, The National Bank of Romania).

The Governor of the National Bank of Romania considered in June 2011 that the actual implementation of IFRS is part of the central bank's area of concerns, since relevant and adequate assessments of credit institutions' assets, debts and shareholders' equity are essential prerequisites for the calculation of real prudential indicators (Isarescu, 2011). 


\section{banks.}

\section{The main differences between IFRS and RAS Romanian Accounting Standards for}

Transition to IFRS claims that Romanian banks replace the old accounting judgments before IFRS with the new accounting standards. The main challenge imposes Romanian banks to understand that IFRS conformity presumes professional accounting judgment and a high degree of subjectivity. Adding, banks have to understand that the IFRS are permanently changing and this aspect imposes banks to adapt their procedures and methodologies.

We synthesize the main topics regarding the comparative approach of conversion of Financial Statements of Romanian banks to IFRS: IFRS Framework, the loan impairment provisions, revenue recognition, recognition and measurement of financial instruments.

IFRS Framework presents the objective of the financial reporting and the user of financial information in the same manner like RAS. Also, IFRS framework contains the basic concepts for preparation and presentation of the financial statements, similar to the concepts contained by the banking RAS, that promote the characteristic of the financial information like IFRS - relevance, materiality, comparability, verifiability, timeliness, understandability. IFRS framework describes the definition, ways of recognition and measurement contained by the financial statements emphasize the possibilities to use the different measurement bases: historical cost, current cost, net realisable value, present value. The same bases are mentioned in the banking RAS.

The loan impairment provisions are considered the main aspect that have to be manage by banks in IFRS adopting, owing to assess the expected future credit losses and volatility in the account of profit or loss. Loan losses provisions affect bank profitability and they are the results of the deterioration in the banks assets' quality and in this context, it is essential to efficiently manage the loan loss provisioning processes. Loan impairment provisions are considered an important topic of IFRS banking transition in the KPMG's study in 2010. It underlined the differences between IFRS and RAS in this area and presented that in 2009, for example, under RAS, banks configured greater provisions because at least $75 \%$ of the recoverable amount of the receive collateral have to be discounted for the worst loans with more than 90 days overdue. According to RAS, the bank can reduce the level of exposures from loans classified as loss, in the case of which the debt service is higher than 90 days and/or in the case of which judicial procedures have started against the operation or the debtor, by taking into consideration at most 25 percent of the value of collateral.

IFRS are more flexible and does not require the same limitation, according to IAS 39 Financial Instruments: Recognition and Measurement and new IFRS 9 Financial Instruments (effective date of IFRS 13 is 1 January 2015. When establish the loan impairment provisions, the banks have to observe that appear the loss events like (IAS 39): a breach of contract, such a default or delinquency in interest or principal payments; if there is the probability of borrower's bankruptcy or financial reorganisation or lender's concession granted to the borrower because the borrower's financial difficulty if the lender would not otherwise consider the concession. Banks have to search evidence of impairment for the loans that are individually significant and if there is no evidence for impairment for the individually loan, then banks have to include the loan in a group of similar assets with similar credit risk characteristics and collectively assesses them for impairment and constitute collectively provisions.

Revenue and its recognition are important to banks in establishing of performance, reason that impose banks to focus on settlement like IASB Exposure Draft 2011/6 Revenue from Contracts with Customers and IAS 18 Revenue. According to IAS 18, banks have two possibilities to recognise the revenue: over time and at a point in time. The new mentioned Exposure Draft supposes that banks use a model that implies: identification of the contract with customer, identification of the separate performance obligation in the contract, determination of the transaction price, allocation of the transaction price to the separate performance obligations and recognision of the revenue when the entity satisfy each performance obligation. Romanian banks have to understand 
Recognition and measurement of financial instruments impose banks to replace the classic approaches in accounting based on the historical cost with fair value measurement, according to IAS 39 Financial Instruments: Recognition and Measurement, new IFRS 9 Financial Instruments and new IFRS 13 Fair Value Measurement (effective date of IFRS 13 is 1 January 2013). IFRS 13 will modify the conceptual approach of fair value, considered the price that would be received to sell an asset or paid to transfer a liability in an orderly transaction between market participants at the measurement date. Banks have to initially recognize the financial assets in one of the amortised cost and fair value categories and for classification and measurement the following models - business model assessments for fair value through other comprehensive income and fair value through profit and loss.

In order to underline the challenges of the IFRS adoption in the Romanian banking system, we develop a case study based on the original individual Financial Statements of Banca Comerciala Carpatica SA for the financial exercise as at 31 December 2011, elaborated in accordance with Order No. 15/2009 of the Chairman of the National Bank of Romania Board with subsequent amendments and additions, regarding to preparing the financial statements according to IFRS. The utilized amounts are hypothetically for the purpose of explain the potential accounting differences between IFRS and the used RAS Romanian Accounting Standards according to European Directives before IFRS adoption. We refer to the Generally Accepted Accounting Principles GAAP until 31 December 2011 in their quality of Romanian accounting norms, issued by the National Bank of Romania NBR. The main Romanian Accounting Standard RAS norm was the Order of the NBR's Governor no. 13/2008 for approving accounting regulations conforming to the European Directives applicable to credit institutions, non-banking financial institutions and Baking System Deposit Guarantee Fund.

The differences between the RAS and IFRS based on comparative figures for 2011, presented in the Annex of this paper, arise from the following examinations. These exemplifications are not exhaustive and refer to the main aspects set in Balance Sheet of a Romanian bank:

Table 1

The differences between the RAS and IFRS based on Balance Sheet of a Romanian Bank

\begin{tabular}{|c|c|c|}
\hline $\begin{array}{c}\text { Item of } \\
\text { Balance } \\
\text { Sheet }\end{array}$ & $\begin{array}{l}\text { Romanian Accounting Standards } \\
\text { RAS according to European } \\
\text { Directives }\end{array}$ & International Financial Reporting Standards IFRS \\
\hline $\begin{array}{l}\text { Public } \\
\text { instruments } \\
(\text { Code } 20)\end{array}$ & $\begin{array}{l}\text { Classified in the investment securities } \\
\text { category. } \\
\text { The bank recognize them at historical } \\
\text { cost at the date of transfer to the bank, } \\
\text { according to the RAS. After their initial } \\
\text { recognition, the investment securities } \\
\text { were evaluated at a value which is the } \\
\text { lower between the purchase value and } \\
\text { the market value and resulted } \\
\text { adjustment for depreciation recognized } \\
\text { in the profit and loss account } 2437 \\
\text { RON. }\end{array}$ & $\begin{array}{l}\text { According to IAS } 39 \text { Financial Instruments: Recognition } \\
\text { and Measurement and IFRS } 9 \text { Financial Instruments, the } \\
\text { same public instruments were classified into financial } \\
\text { assets held for trading, that are initially registered at fair } \\
\text { value adding the marginal costs for acquisition or } \\
\text { emission. At the balance sheet date, the financial assets } \\
\text { held for trading were recognized at fair value and was } \\
\text { annulled the adjustment for depreciation and resulted a } \\
\text { decreasing of the reserve for the financial assets held for } \\
\text { trading } 120 \text { RON and deferred tax on profit liability } 370 \\
\text { RON. }\end{array}$ \\
\hline $\begin{array}{l}\text { Receivables } \\
\text { over clients } \\
(\text { Code } 40)\end{array}$ & $\begin{array}{l}\text { The bank determined the adjustments } \\
\text { for depreciation according to the } \\
\text { National Bank of Romania's Regulation } \\
\text { no. } 3 / 2009 \text { on classification on loans } \\
\text { and investments as well as the } \\
\text { establishment, the restatement and the } \\
\text { use of specific provisions for credit risk } \\
\text { with subsequent amendments and } \\
\text { additions. Bank applied three criteria in }\end{array}$ & $\begin{array}{l}\text { According to IAS } 39 \text { Financial Instruments: Recognition } \\
\text { and Measurement and IFRS } 9 \text { Financial Instruments, the } \\
\text { loan and advances recorded at amortised cost were } \\
\text { evaluated at the balance sheet date, if there are proves of } \\
\text { individual or collective impairment. } \\
\text { In the case in which banks obtain proves and evidence of } \\
\text { the impairment loss on loans and receivables or held-to- } \\
\text { maturity investments and that were registered at amortised } \\
\text { cost, the amount of the loss represents the difference }\end{array}$ \\
\hline
\end{tabular}




\begin{tabular}{|c|c|c|}
\hline $\begin{array}{c}\text { Item of } \\
\text { Balance } \\
\text { Sheet }\end{array}$ & $\begin{array}{c}\text { Romanian Accounting Standards } \\
\text { RAS according to European } \\
\text { Directives }\end{array}$ & International Financial Reporting Standards IFRS \\
\hline & $\begin{array}{l}\text { order to classify the loans: the debt } \\
\text { service, the financial performance and } \\
\text { start of judicial procedures. The credit- } \\
\text { related exposures that lenders incur in } \\
\text { their relationship with debtors from } \\
\text { outside the credit institution sector fall } \\
\text { into several categories, as follows: } \\
\text { Standard S; Watch W; Substandard SS; } \\
\text { Doubtful D; Loss L. }\end{array}$ & $\begin{array}{l}\text { between the asset's carrying amount and the present } \\
\text { value of estimated future cash flows (from which are } \\
\text { excluded future credit losses that have not been incurred) } \\
\text { discounted at the financial asset's original effective } \\
\text { interest rate. } \\
\text { For the purpose of a collective evaluation of impairment, } \\
\text { financial assets are grouped according to the internal } \\
\text { scoring system of the bank on the basis of credit risk } \\
\text { characteristics that are indicative of the debtors ability to } \\
\text { pay all amounts due according to the contractual terms } \\
\text { (for example, on the basis of a credit risk evaluation or } \\
\text { grading process that considers asset type, geographical } \\
\text { location, collateral type, past-due status and other relevant } \\
\text { factors). } \\
\text { The different methodologies (RAS and IFRS) for } \\
\text { impairment loss on loans determine and accruals income } \\
\text { determine a difference in amount of receivables over } \\
\text { clients } 141975 \text { RON. }\end{array}$ \\
\hline $\begin{array}{l}\text { Bonds and } \\
\text { other } \\
\text { securities } \\
\text { with flat } \\
\text { income (Code } \\
\text { 50) }\end{array}$ & $\begin{array}{l}\text { These are bonds and other securities } \\
\text { with flat income issued by credit } \\
\text { institutions or other public institutions, } \\
\text { if they are not exhibit at code } 20 \text { Public } \\
\text { instruments. The same approach like } \\
\text { Code 20. Adjustment for depreciation } \\
3748 \text { RON. }\end{array}$ & $\begin{array}{l}\text { According to IAS } 39 \text { Financial Instruments: Recognition } \\
\text { and Measurement and IFRS } 9 \text { Financial Instruments, the } \\
\text { bonds were classified into financial investments held for } \\
\text { trading, that at the balance sheet date were recognized at } \\
\text { fair value. It records a reserve for the financial } \\
\text { investments } 7777 \text { RON and a receivable for deferred tax } \\
\text { on profit } 1244 \text { RON. }\end{array}$ \\
\hline $\begin{array}{l}\text { Equity } \\
\text { investments } \\
\text { (Code } 70)\end{array}$ & $\begin{array}{l}\text { Equity investments are initial } \\
\text { recognition at historical cost and at the } \\
\text { balance sheet date at historical cost } \\
\text { from which were deducted the } \\
\text { adjustment for depreciation. }\end{array}$ & $\begin{array}{l}\text { According to IAS } 39 \text { Financial Instruments: Recognition } \\
\text { and Measurement and IFRS } 9 \text { Financial Instruments, the } \\
\text { investments were classified into financial investments } \\
\text { held for trading, that at the balance sheet date were } \\
\text { recognized at cost, because fair value could not be } \\
\text { determined. } \\
\text { According to IAS } 29 \text { Financial Reporting in } \\
\text { Hyperinflationary Economies the bank evaluated the } \\
\text { equity investments and resulted a difference } 302 \text { RON. }\end{array}$ \\
\hline $\begin{array}{l}\text { Interests in } \\
\text { associate } \\
\text { undertakings } \\
(\text { Code } 80)\end{array}$ & $\begin{array}{l}\text { The interests are initial recognition at } \\
\text { historical cost and at the balance sheet } \\
\text { date at fair value. Unfavorable } \\
\text { differences impose provisions. }\end{array}$ & $\begin{array}{l}\text { According to IAS } 39 \text { Financial Instruments: Recognition } \\
\text { and Measurement and IFRS } 9 \text { Financial Instruments, the } \\
\text { interests were classified into financial investments held } \\
\text { for trading, that at the balance sheet date were recognized } \\
\text { at cost, because fair value could not be determined. } \\
\text { According to IAS } 29 \text { Financial Reporting in } \\
\text { Hyperinflationary Economies the bank evaluated the } \\
\text { interests and resulted a difference } 147 \text { RON. }\end{array}$ \\
\hline $\begin{array}{l}\text { Other assets } \\
\text { (Code 120) }\end{array}$ & Deferred tax on profit is not recognised. & $\begin{array}{l}\text { According to IAS } 12 \text { Income Taxes the bank recognized } \\
\text { the deferred tax liability for all taxable temporary } \\
\text { differences - deferred tax assets and liabilities. Deferred } \\
\text { tax assets } 88 \text { RON are the amounts of income taxes } \\
\text { recoverable in future periods in respect of deductible } \\
\text { temporary differences, the carryforward of unused tax } \\
\text { losses and the carryforward of unused tax credits. }\end{array}$ \\
\hline
\end{tabular}

These examples intend to underline the accounting judgment in two accounting different frameworks and conduct towards the necessity that banks aware the essential need to continue adapt their informatics systems at the new IFRS accounting norms, through the implementation of the new applications convergent to IFRS using the existing data and new procedures. A usual, the informatics banking system will play a defining role in the banks' activity and a adequate 
developing of this system can contribute to the right leading of the bank and to the preparing of the financial statements on the IFRS basis.

\section{Audit approach}

The financial statements of the year ending to 31 December 2012 will be the first issued according to the new accounting rules based on IFRS and at the data of the present paper there are not published yet the banking financial statements according to IFRS. Our approach represents a forward-looking landing of the challenges of the audit of the IFRS banking financial statements. To investigate the influence of the banking accounting rules according to IFRS on the audit process, we use the Auditors' Reports for the year 2011 of the listed Romanian banks at the Bucharest Exchange Stock. Only three banks are listed at the Bucharest Exchange Stock - Banca Transilvania SA, BRD - Groupe Societe Generale SA and Banca Comerciala Carpatica SA. The financial individual statements of all three societies were audited by the companies from Big Four and the Auditors' Reports contain unqualified opinion for the financial statements for the financial exercise ending 31 December 2011. We remark the auditors' opinions that the individual financial statements of these banks have been prepared in all material respect according to Romanian Accounting Standards National Bank of Romania's Order 13/2008. Except qualifying their opinions, the auditors emphasized (for the Banca Transilvania SA) the possibility of appearance of the subsequent events, after the beginning of 2012, referring to the new IFRS standards applicable from 1 January 2012. Consequently, we deduce that the IFRS applications in Romanian banks represent for the banks' auditors an important factor which they consider when perform an banking audit.

Auditors have to familiarize theyself with the new banking accounting regulations based on IFRS, especially the fine aspects of tax impact of IFRS conversion adjustments, including the adjustments according to IAS 29 Financial Reporting in Hyperinflationary Economies, the qualitative characteristics of financial information, the loan impairment, the fair value of the financial instruments and other types of adjustments based on applying of the IFRS in Romanian banks - deferred tax, employee benefits, impairment of non-financial assets. We recognize the audit's role in monitoring the accounting standards compliance in banks. According to IAPS 1004 International Auditing Practice Statement (IAPS 1004 The relationship between banking supervisors and banks' external auditors) the financial statements of the banks are the subject of the independent audit, that express an opinion regarding to the bank's financial statements if they are prepared, in all material respects, in accordance with the applicable financial reporting framework. Also, the adequacy of the banking accounting procedures and systems is one of the external auditor's duties. The main raw material for the independent auditor's mission represents the financial statements of a bank, which are prepared under the bank's management responsibility.

The auditor has to ensure that the financial statements are complete and according to the financial reporting framework. Beginning to the financial exercise 2012, the financial reporting framework applied in the Romanian banking system consists in IFRS. Main beneficiaries of the audit bank report are the shareholders of the bank and the executive management, while others users of the audit report could remain interested in the bank's financial statements and audit report, but are not the primary addressees.

The audit report on the financial statements of the bank must not be interpreted as guarantee of the future profitability of the bank or of its stability. The audit report contributes to the credibility of the bank's financial statements and for this, the independent auditor have to do one's best to design audit procedures for reducing the risk of an inappropriate audit opinion at an admissible low level.

Generally, the active banks from Romania are audited by the branches of the audit companies belonged to the international professionals in audit from Big Four. This consists in a great advantage for banks, that can benefit from an professional independent audit opinion, as a result of experience of audit companies from Big Four in banking audit of financial statements 
according to IFRS. These companies audit overwhelming majority of the financial institutions around the world and set out the proper procedures to perform an audit in the banking field.

The auditors of the active banks from Romania have to understand the national specificities of the new accounting regulations if they exist and have to use professional judgment for decide upon the nature, timing and extend of the audit procedures, in order to obtain the reasonable assurance on the bank's financial statements. We consider that all the audit stages are affected by the new IFRS banking rules and auditors have to quantify the influence of the new accounting rules on their work. For the next financial statements after 2012, the new banking accounting regulations will change the auditors' approach, especially:

- when auditors understand the banking business (ISA 315 Identifying and Assessing the Risks of Material Misstatement through Understanding the Entity and Its Environment);

- when auditors plan the audit (ISA 300 Planning an Audit of Financial Statements);

- when auditors understand the nature of banking risks and make the assessment of materiality (ISA 315 Identifying and Assessing the Risks of Material Misstatement through Understanding the Entity and Its Environment, ISA 320 Materiality in Planning and Performing an Audit, ISA 330 The Auditor's Responses to Assessed Risks);

- when auditors understand the accounting and control system and when they identify, document and test control procedures (ISA The Auditor's Responsibilities relating to Fraud in an Audit of Financial Statements, ISA 250 Consideration of Laws and regulations in an Audit of Financial Statements, ISA 265 Communicating Deficiencies in Internal Control to those Charged with Governance and Management);

- when auditors perform substantive procedures and obtain the audit evidence (ISA 500 Audit Evidence, ISA 520 Analytical Procedures, ISA 530 Audit Sampling, ISA 540 Auditing Accounting Estimates, including Fair Value Accounting Estimates, and Related Disclosures);

- when auditors conclude and report on an banking audit (ISA 700 Forming an Opinion and Reporting on Financial Statements, ISA 705 Modifications to the Opinion in the Independent Auditor's Report, ISA 706 Emphasis of Matter Paragraphs and Other Matter Paragraphs in the Independent Auditor's Report).

\section{Conclusions}

We find evidence which suggests that there is a significant relationship between the accounting banking regulations based on IFRS and banking audit process. This assumption is based on the studying of the Auditors' Reports for the year 2011 of the listed Romanian banks at the Bucharest Exchange Stock. For the financial statements of year 2011, auditors are concerned in establish the effect of the subsequent events, after the beginning of 2012, referring to the new IFRS standards applicable from 1 January 2012.

The paper mentions some specialized studies regarding to IRFS adoption in the banking systems, especially in Europe, for the purpose of emphasizing the actual tendencies in banking accounting and the synoptically evolution of the IFRS standards' application in banks. As we expected, IFRS are considered to be an accounting language of the future and Romania ranges to this basic tendency, through the IFRS adopting in banks starting with 1 January 2012. The advantages of the IAS/IFRS adoption are recognized in the banking filed, where the globalization of the businesses are more pregnant than in others domains.

To understand what newness bring IFRS for the Romanian banking sector, we theoretically synthesize the main few topics regarding the comparative approach of conversion of financial statements of Romanian banks to IFRS: IFRS Framework, the loan impairment provisions, revenue recognition, recognition and measurement of financial instruments. Then, without exhaustive pretensions, based on the Balance Sheet of a Romanian bank, we develop a study case to present some examples for stressing the differences between RAS Romanian Accounting Standards according to European Directives and IFRS for the following issues: public instruments, receivables 
over clients, bonds and other securities with flat income, equity investments, interests in associate undertakings, deferred tax liabilities. The necessity of the IFRS basis informatics banking systems is recognized. It is underlined the independent audit challenges to adapt to the IFRS accounting banking rules.

From the reviewer of the IFRS adoption in the Romanian banking system, we conclude that the banks' independent auditors have to endeavor to understand the new accounting IFRS rules and must develop appropriate audit procedures to perform an audit. Significant accounting judgment is necessary for the Romanian banks in IFRS application and this is a provocation too for the independent audit of the banks.

The further research in the field will focus on examining in the more complex analyses of the elements of the banking financial statements on the IFRS basis and how they can affect the audit of the banks.

\section{References}

1. Agostino M., Drago D., Silipo D.B., 2011. The value relevance of IFRS in the European banking industry, Review Quantitative Finance and Accounting, No. 36, pp. 437-457

2. Anandarajan A., Francis B., Hasan I., John K., 2011. Value relevance of banks: global evidence, Review of Quantitative Finance and Accounting, Issue 1, Vol. 36, p. 33-55

3. Ballas A.A., Skoutela D., Tzovas C.A., The relevance of IFRS to an emerging market: evidence from Greece, Managerial Finance, Vol. 36, Issue 11, pp. 931-948

4. Bansal A., Prusty R., Tanna J.J., Denis L., 2011. Convergence to IFRS - Issues for banking sector, Lachoo Management Journal, Vol. 2, No. 1, pp. 1-8.

5. Biondi Y., Suzuki T., 2007. Socio-economic impacts of international accounting standards: an introduction, Socio-Economic Review, No. 5, pp. 585-602.

6. Brown A.M., 2004. The Milieu of the IASB', Journal of American Academy of Business, no. 5, pp. 385-391.

7. Basel Committee on Banking Supervision, 2011. Basel III: A global regulatory framework for more resilient banks and banking systems, available online at http://www.bis.org/publ/bcbs189.pdf

8. Basel Committee on Banking Supervision, 2004. International Convergence of Capital Measurement and Capital Standards - a revised framework, available online at http://www.bis.org/publ/bcbs107.pdf

9. Christensen H.B., 2012. Why do firms rarely adopt IFRS voluntarily? Academics find significant benefits and the cost appear to be low, Review of Accounting Studies, vol. 17, No. 3, pp. 518-525.

10. Financial Statements of Banca Comerciala Carpatica SA for the financial exercise as at 31 December 2011, elaborated in accordance with Order No. 15/2009 of the Chairman of the National Bank of Romania Board with subsequent amendments and additions, regarding to preparing the financial statements according to IFRS, available online at http://www.carpatica.ro/sws_site/file/Situatii\%20financiare\%20IFRS\%20indiv.pdf.

11. Firoz M., Anzari A., Akhtar K., 2011. IFRS - Impact on Indian Banking Industry, International Journal of Business and Management, Vol. 6, No. 3, pp. 277-283

12. Gebhardt G., Novotny-Farkas Z., 2010. The effect of IFRS adoption on the financial reporting quality of European banks, Marie Curie Research Training Network. The IFRS Revolution: Compliance, Consequences and Policy Lessons, INTACCT.

13. IAPS 1004 International Auditing Practice Statement - The relationship between banking supervisors and banks' external auditors

14. International Monetary Fund, 2012. Basel Core Principles for Effective Banking Supervision - Detailed Assessment of Observance, Czech Republic. 
15. Isarescu M., 2011. Opening speech at the IFRS conference International Financial Reporting Standards - International experience and implementation by the banking sector in 2012 http://www.bis.org/review/r110623f.pdf.

16. KPMG, 2010. IFRS: Are you ready? The race is on, KPMG Survey of the Romanian Financial Institutions' Use of International Financial Reporting Standards compared with Romanian Accounting Standards, available online at http://www.kpmg.com/RO/en/topics/Documents/IFRS_Are_you_ready_final.pdf

17. Larson R.K., Street D.L., 2004. Convergence with IFRS in an expanding Europe: progress and obstacles identified by large accounting firms' survey, Journal of International Accounting, Auditing and Taxation, Issue 13, pp. 89-119

18. Order of the National Bank of Romania no. 27 from 2010 regarding to the approval of accounting settlements according to the International Financial Reporting Standards for credit institution, published in Official Gazette no. 890/2010.

19. Order of the National Bank of Romania no. 26 from 2010 regarding to the modification and completing the accounting settlements according to the European Directives for credit institution, non-banking institutions and FGBD, approved by NBR's Order no. 13/2008, published in Official Gazette no. 886/2010.

20. Socol A., 2011. Loan Losses Provisioning Processes In Romanian Banks During January 2007 - February 2011, Annales Universitatis Apulensis Series Oeconomica, Issue 13(1), pp. 106-112

21. Stefan C., 2011. National Bank of Romania, Settlements in the IFRS Implementation Context, available online at http://www.bnro.ro/IFRS-experienta-internationala-siimplementarea-acestora-de-catre-sectorul-bancar-din-Romania-in-2012-7052.aspx. 
ANNEX

Table 1

Balance Sheet of a Romanian Bank - RON

\begin{tabular}{|c|c|c|c|c|}
\hline ASSETS & CODE & FINANCIAL & XXRCISE & DIFFERENCES \\
\hline & & $\begin{array}{c}\text { AMOUNTS } \\
\text { ACCORDING TO } \\
\text { INTERNATIONAL } \\
\text { FINANCIAL } \\
\text { REPORTING } \\
\text { STANDARDS - } \\
\text { IFRS }\end{array}$ & $\begin{array}{c}\text { AMOUNTS } \\
\text { ACCORDING } \\
\text { TO ROMANIAN } \\
\text { ACCOUNTING } \\
\text { STANDARDS - } \\
\text { RAS }\end{array}$ & $\begin{array}{c}\text { BETWEEN } \\
\text { IFRS AND RAS }\end{array}$ \\
\hline Cash and balances at central banks & 10 & 808599 & 808599 & 0 \\
\hline $\begin{array}{l}\text { Public instruments and other securities } \\
\text { accepted for refinancing at central banks }\end{array}$ & 20 & 2681809 & 2679492 & 2317 \\
\hline - public instruments and assimilated values & 23 & 2681809 & 2679492 & 2317 \\
\hline $\begin{array}{l}\text { - other securities accepted for refinancing at } \\
\text { central banks }\end{array}$ & 26 & 0 & 0 & 0 \\
\hline Receivables over credit institutions & 30 & 16069 & 16069 & 0 \\
\hline - sight & 33 & 8084 & 8084 & 0 \\
\hline - other receivables & 36 & 7984 & 7984 & 0 \\
\hline Receivables over clients & 40 & 1662476 & 1520501 & 141975 \\
\hline Bonds and other securities with flat income & 50 & 482235 & 493760 & $(11525)$ \\
\hline - issued by public bodies & 53 & 115818 & 122232 & $(6413)$ \\
\hline - by other issuers, of which: & 56 & 366417 & 371528 & $(5112)$ \\
\hline - own bonds & 58 & 0 & 0 & 0 \\
\hline $\begin{array}{l}\text { Shares and other securities with variable } \\
\text { income }\end{array}$ & 60 & 62680 & 62680 & 0 \\
\hline Equity investments, of which: & 70 & 1620 & 1318 & 302 \\
\hline - equity investments in credit institutions & 75 & 0 & 0 & 0 \\
\hline Interests in associate undertakings, of which: & 80 & 41611 & 41464 & 147 \\
\hline - investments in credit institutions & 85 & 0 & 0 & 0 \\
\hline Intangible assets, of which: & 90 & 9478 & 9478 & 0 \\
\hline - start up expenses & 93 & 0 & 0 & 0 \\
\hline $\begin{array}{l}\text { goodwill, if acquired for good and valuable } \\
\text { consideration }\end{array}$ & 96 & 0 & 0 & 0 \\
\hline Tangible assets, of which: & 100 & 258976 & 258976 & 0 \\
\hline - land and building used in own activity & 105 & 234343 & 234343 & 0 \\
\hline Unpaid subscribed capital & 110 & 0 & 0 & 0 \\
\hline Other assets & 120 & 123077 & 123165 & $(88)$ \\
\hline Prepaid expenses and accrued income & 130 & 43822 & 43822 & 0 \\
\hline TOTAL ASSETS & - & 6192452 & 6059323 & 133128 \\
\hline
\end{tabular}

Source: Hypothetic amounts based on Romanian banks' Balance Sheet template

Table 2

Off Balance Sheet Items of a Romanian Bank - RON

\begin{tabular}{|c|c|c|c|c|}
\hline \multirow[t]{2}{*}{ OFF BALANCE SHEET ITEMS } & \multirow[t]{2}{*}{ CODE } & \multicolumn{2}{|c|}{$\begin{array}{l}\text { FINANCIAL EXERCISE } \\
\end{array}$} & \multirow{2}{*}{$\begin{array}{l}\text { DIFFERENCES } \\
\text { BETWEEN } \\
\text { IFRS AND RAS }\end{array}$} \\
\hline & & $\begin{array}{c}\text { AMOUNTS } \\
\text { ACCORDING TO } \\
\text { INTERNATIONAL } \\
\text { FINANCIAL } \\
\text { REPORTING } \\
\text { STANDARDS - } \\
\text { IFRS }\end{array}$ & $\begin{array}{c}\text { AMOUNTS } \\
\text { ACCORDING TO } \\
\text { ROMANIAN } \\
\text { ACCOUNTING } \\
\text { STANDARDS - } \\
\text { RAS }\end{array}$ & \\
\hline Contingent liabilities, of which: & 600 & 43259 & 43259 & 0 \\
\hline - acceptances and endorsements & 603 & 43239 & 43239 & 0 \\
\hline - guarantees and pledged assets & 606 & 20 & 20 & 0 \\
\hline Commitments, of which: & 610 & 352886 & 352886 & 0 \\
\hline $\begin{array}{l}\text { - commitments arising of sale transactions } \\
\text { with possible repurchase }\end{array}$ & 615 & 0 & 0 & 0 \\
\hline
\end{tabular}

Source: Hypothetic amounts based on Romanian banks' Balance Sheet template 